\title{
Studies of Nematocysts
}

$\mathrm{I}^{\mathrm{N}}$ a work of 700 pages (Travaux de la Station Zoologique de Wimereux, 10 and 11. Paris: Laboratoire d'évolution des êtres organisés, 1934. 125 frs. each) Robert Weill describes the results of his detailed observations on the Cnidaria with special reference to their nematocysts. His investigations have been made largely on fresh material derived from 113 species of coelenterates.

A short historical summary is followed by a careful description of a nematocyst-an ovoid capsule with a circular opening at the narrow end closed by an operculum, and here the wall of the capsule is continuous with the tube enclosed in the capsule; the basal part of the tube is generally wider and straight, the distal part narrow and spirally coiled, and both parts of the tube have on the inner surface numerous spines inserted in groups of three. The tube is discharged through the terminal aperture and the remains of the operculum are usually demonstrable; at the same time the refringency of the capsule is lost, for its contents have been expelled. The author describes the wide variations in size of the nematocysts, from $5 \mu$ in length in some Alcyonaria to $1 \cdot 12$ $\mathrm{mm}$. in length in the siphonophore Halistemma.

Weill classifies the different types of nematocysts into those with closed tube, of which there are three kinds, and those in which the tube is open at its tip, of which fourteen kinds are recognised. $\mathrm{He}$ discusses the question of nerve supply to the nematocyst cell and concludes provisionally that a nervous connexion is unlikely. The author is very decided that the discharge of the tube is not by its unbending, like a spring, but by its devagination, for by retarding the process the stages of extroversion can be followed under the microscope. The tube is longer and wider after discharge-it may be doubled in length-hence its wall is elastic and in the undischarged nematocyst is in a state of disequilibrium. After discussing the mechanism of discharge, the author, accepts the view of Iwanzoff (1896) that the discharge is due to swelling of the contents of the capsule. Discharge can be brought about only in presence of fluid which penetrates the capsule, but what determines the endosmosis is not yet known.

The author describes his observations on the development of nematocysts, and traces the migrations of the nematocyst cells, for example, in the Lucernaridæ, from their origin in thickened ectoderm at the edge of the subumbrella to the tentacular knobs. Fully formed nematocysts appear to remain functional indefinitely. About three hundred pages are devoted to a consideration of the taxonomic value of the cnidome, that is, the ensemble of the nematocysts presented by a particular species of cœlenterate. In discussing the Gymnoblastea, considered to be an artificial and heterogeneous group, Weill considers that Hydra represents not a primitive but one of the most complex genera, and should be placed near the Tubulariidæ. The study of the cnidome confirms the distinction between the Milleporidæ, which are allied to Gymnoblastea, and the Stylasteridæ, which are near the Calyptoblastea. Incidentally, the author does not accept Willey's observation that the filament of a discharged nematocyst of Millepora can be withdrawn or retracted. In their cnidome the Scyphozoa approximate more to the Hydrozoa than to the Anthozoa. Alcyonaria have a homogeneous cnidome different from that of Zoantharia. The bearing of the cnidome on the classification of anemones and corals is discussed.

This important monograph concludes with an extensive bibliography and an index of the genera and species referred to in the work.

\section{British Association at Dublin in I835}

$\mathrm{T}$ HE fifth meeting of the British Association was held at Dublin during the week beginning August 10, 1835. The president was Dr. Bartholomew Lloyd (1772-1837), provost of Trinity College, Dublin, the vice-presidents, Lord Oxonantown and the Rev. William Whewell, while the local secretaries were William Rowan Hamilton (1805-1865), Astronomer Royal of Ireland, and Humphrey Lloyd (1800-1881), Erasmus Smith professor of natural and experimental philosophy. The scientific proceedings were dealt with in six sections: (I) Mathematies and Physics ; (II) Chemistry and Mineralogy ; (III) Geelogy and Geography; (IV) Zoology and Botany; (V) Anatomy and Medicine; and (VI) Statistics, to which was added during the meeting the subsection on Mechanical Science Applied to the Arts. The meeting was largely attended, and there was a great deal of entertaining. Among the most famous men of science who were present were Sedgwick, Ross, Franklin, Agassiz, Dalton, Lardner, Babbage,
Murchison, Rennie, Sabine, Wheatstone, Scott Russell and Eaton Hodgkinson. During the meeting the University conferred degrees upon William Smith, Sir Thomas Brisbane, Francis Baily, Prof. Moll and M. Agassiz.

Official reports of the proceedings were communicated to the editors of the Philosophical Magazine, and the daily papers gave accounts of some of the meetings. Perhaps the liveliest reports of the meeting were those published in the Athenoeum of August 15, 1835 , and succeeding issues, and from these a few extracts have been taken. The first portion of the report said: "The British Association has received, as we anticipated, a great accession to its members in Dublin, though many who intended to join it have been detained by their Parliamentary duties and by the Assizes. Still so many candidates presented themselves that the local council was compelled to place some restrictions on admission and to refuse, unless under special circumstances, all 
applications made after Wednesday, the 5th of August, by persons residing in Dublin. ... The arrangements made by the reception committee were excellent. . . Accommodations were provided for a great number of guests within the walls of the College, and arrangements made for their breakfasting and dining together in the College Hall, by which the intercourse between the members has been greatly facilitated. ...."

On Saturday, August 8, the Examination Hall of Trinity College was crowded. "Sir John Ross, Sir John Franklin, Dr. Coulter, the recent explorer of Mexico, Dr. Dalton, Dr. Roget, Professors Babbage, Powell, Murchison and many other eminent men, were among the crowd, evidently enduring some inconvenience, that they might gratify the curiosity they had excited. . . . In the list of names of mermbers admitted on Saturday were to be found men of every creed, sect and party-Protestant clergymen, Catholic priests, and dissenting ministers-all anxious to gain a respite from agitating controversies, and enjoy a week's repose on the neutral ground of science. Visitors streamed into Dublin by the packet boats on Monday morning but by about eleven o'clock the whole of the Sections were in working order. The General Meeting of the Association took place in the Rotunda where Dr. Lloyd delivered his address and Prof. Hamilton read a report. The last function was a farewell dinner given by the Provost and Fellows of Trinity College to the Lord Lieutenant, Lord Musgrave, and 300 of the members of the Association. Just before the dinner Lord Musgrave conferred a knighthood on Hamilton, remarking in his speech, "This is an exercise of one of those prerogatives of royalty, of which I am here the representative, most grateful to myself-most in unison I feel assured with the wishes of that august sovereign on whose behalf I act. . . . This act does not so much confer distinction, as place the royal, and therefore national, stamp upon that distinction, which has been aequired by personal qualifications and individual executions.' . . ."

In his summing up of the meeting, the correspondent of the Athenaeum wrote: "The meeting of the Association is now over and before we proceed to draw up a record of its proceedings we must say a few words on the general results of the week, and the impression left on our minds. On former occasions hospitality has been shown by the residents of the place of the assemblage to the way-faring visitors, and the business has preserved the 'even tenor of its way'; but in Dublin, notwithstanding the unusual quantity and quality of the scientific communications, business has been positively perplexed by the joyousness and festivities of the occasion. ... Setting aside the distraction of mind incidental to the crowding together so much business ... the vast number of all classes and pretensions who have joined the Association, and flocked to its halls, cannot have but disturbed the march of the proceedings. Imagine the Rotunda-a room capable of accommodating from 1,500 to 2,000 individualsthronged to excess on some of the hottest evenings of this hot and cometary season: the ladies flirting and fanning; the gentlemen casting one eye upon Science and another upon Beauty; and the whole (saving the reader's presence) mopping and puffing and ready to drop with exhaustion and fatigue. . . . Even in the Sections themselves, the scientific men were not left in peace; both sexes were eager to attend them; and the ladies, as they could not be in the whole at once, made the best of their case by crowding in shoals to that particular section where the business was of the most abstract and recondite character. .. The admission of ladies at the Sectional meetings, in direct opposition to the standing rule of the Association, is so manifestly calculated to destroy the efficiency of the Society, that we trust that there will be no repetition of this impropriety".

The treasurer of the Association in his report said that the receipts of the preceding year in Edinburgh were $£ 1,626$, while in Dublin they amounted to $£ 1,750$. It was very gratifying to be able to state that grants for the advancement of seience of $£ 1,700$ had been placed at the disposal of the committee in 1835 .

\section{Educational Topics and Events}

Cambridge.--F. R. Parrington, of Sidney Sussex College, has been appointed University demonstrator in zoology, and Dr. R. Knox and Dr. G. P. MeCullagh have been appointed University demonstrators in pathology.

The Marmaduke Shield Scholarship for 1935 has been awarded to G. W. Harris, of Emmanuel College.

The offer of the Rev. J. H. T. Perkins, to give to the University a sum for the establishment of a Michael Perkins Fund, the interest of which is to be employed in making grants to young graduates working upon the natural history of animals, has been gratefully accepted.

Dr. Margarex S. SMith has been appointed lecturer in agricultural chemistry and physics at the Horticultural College, Swanley, Kent, and will take up her duties in September.

The University of Durham Act, 1935, which has now received the Royal Assent, sets up the following body as the University of Durham Commissioners for making Statutes for the University and its constituent divisions and colleges: The Rev. F. H. Dudden (chairman); Countess Grey ; Sir W. Ross Barker; Prof. J. H. Priestley; Mr. C. Williams; Dr. G. R. Murray; Dr. T. F. Sibly ; and Dr. A. Wood. Mr. A. C. Dawes will act as Secretary to the Commissioners.

The New South Wales Ministry of Public Instruction in its last annual report gives information on the progress of its system of correspondence teaching, a system which some authorities in America would adopt in certain sparsely populated areas. The average enrolment of pupils taught by correspondence was 5,300 in primary and 210 in secondary grades, and the system, begun fifteen years ago, is reported to be still meeting with marked success. The provision of secondary education up to the intermediate standard was a new development, the outlook of which is promising. In each section of the primary department a special class of backward pupils receive special treatment. A weekly half-hour broadcast from the correspondence school is a feature said to be much appreciated and is used for answering questions. Associated with the system are voluntary donations by the pupils, amounting up to date to more than a thousand pounds, towards certain charities for the benefit of children. 